lịjk jaarlijks uitbetaald loon. Is dus schade + admin.-kosten b.v. $f 20.000$ : en het aangesloten loonbedrag $f$ 1.000.000, dan wordt de omslag $20 \%$.

IIet ligt voor de hand, dat de Bedrijfsvereeniging, teneinde dit stelsel op de juiste wijze te kumnen toepassen, allereerst nauwkeurige loon-opgaven van de bij hall aangesloten werkgevers moet ontvangen.

Het is gebruikelijk dat in het begin van ieder bockjaar door het Bestuur der Bedrijfsvereeniging wordt geheven een z.g. „voorschot"'premie - eveneens cen fractic van het jaarlijks uitbetaald loon - terwijl aan het einde van het boekjaar afr'ckening volgt.

In de meeste groote industriecle bedrijven bestaat een moderne loon-administratie en levert het opgeven van het jaarlijks uitbetaald loon niet het minste bezwaar op.

Bovendien zijn vele dezer bedrijven ,eigen risico-drager" of wel ,afdeelingskas" en zijn humne loon-opgaven voor de Bedrijfsvereeniging slechts van indirect belang.

Weliswaar is de Bedrijfsvereeniging gal'ant voor de verplichting van „Afdeelingskas" of „Ligen risicodrager" (Ziektewet 1929 Art. 96 lid 1 sub a.) doch zij elimineert hare financieele aansprakelijkheid door deze aangeslotenen een alleszins voldoende zekerheid te doen stellen. Een direct financieel belang bij de juistheid der loon-opgaven dezer eategoric werkgever's heeft zij derhalve niet.

Gcheel anders daarentegen staat zij daarentegen tegenover de volledig-verzekerde ondernemingen, die cen omslagpremic betalen. Daar de te betalen onslagpremic, zooals wij boven opmerkten, is ecn fractie van het, in het desbetreffende boekjaar. uithetaalde loon, is het wel duidelijk, dat hier juiste loonopgaven absoluut noodzakelijk zijn.

In het algemeen geeft ook in deze categorie dit punt geen moeilijkheden; wel kan men opmerken dat er, tengevolge van misverstand, interne bedrijfs-eigenaardigheden, en hclaas ook wel gebrek aan saamhoorigheidsgevocl, vrij vele ,twijfelgevallen" zijn.

Misverstanden ontstaan dikwijls door het feit, dat onze Suciale Verzckering nog altijd niet is unificeerd on de loonopgaven voor de ongevallen-wet 1921 en die voor de Ziektewet 1929 niet gelijk kunnen zijn. Voor de Ongevallenwet 1921 geeft men op de loonen van alle enployé's, vour de Ziektewet 1929 de loonen van hen, die $f 3000$.- of minder verdienen. In vele gevallen is het een, overigens zeer vergeeflijice en begrijpelijke, onbekendheid met onze Sociale Verzekeringswetten, die aanleiding kan geven tot misverstand.

In de tweede plaats noemden wij, ,interne bedrijfseigenaardigheden". Er zijn bedrijven, zoo bijv. het aannemersbedrijf, waar over twee opcenvolgende jaren het uitbetaalde loon zeer sterk kan verschillen. Ook komen juist in deze eategorie nog betrekkelijk vele bedrijven met een zeer embryonale administratie voor.

Het logische gevolg hicrvan is, dat deze categorie den bedrijfsvereenigingen veel hoofdbreken kosten. $\mathrm{E}_{\mathrm{r}}$ zijn instellingen die het recht hebben - neergelegd in de statuten - om de juistheid der loonopgaven te verifieeren. Soms hebben zij speciaal daarvoor ambtenaren in dienst, die het geheele land afreizen. Het feit, dat en dergelijke maatregel ,rendabel" is, toont m.i. wel afdoende aan, dat er belangrijke afwijkingen voorkomen.

ILet derde, door mij genoemde punt, gebrek aan saamhoorigheidsgevocl, is een speciale moeilijkheid, waarop ik hier niet zal ingaan. Gelukkig komt dit euvel slechts zeer sporadisch voor.

De beide andere oorzaken van misverstanden kunnen echter m.i. zeer wel met behulp der Accountants aanzienlijk worden beperkt, indien al niet geheel uitgeschakeld.

Wanneer door samenwerking van Verzekerings-organen en Accountants wordt ingevoerd een uniform stelscl van loon- administratie, zal reeds daardoor het aantal vergissingen belangrijk worden beperkt.

Eveneens kan veel noodeloos onderzoek worden voorkomen, wanneer bij bclangrijke loonverschillen door den deskundige op het formulier de oorzaak van het verschil wordt aangegeven, zoodat de administratie der Bedrijfsvereeniging hare onderzoekingen belangrijk kan beperken. Bovendien kumnen door deze samenwerking met Acceuntants nog andere, indircete voordeelen worden bercikt, daar aldus het publiek door de Accountant zal worden opgevoed tot eene betere kennis van on meer waardeering voor de Sociale Wetgeving.

In hoeverre aanleiding bestaat tot samenwerking met de Rallen v. Arbeid, vermag ik niet te beoordcelen. 1)e genoemde punten echter komen mij reeds bclangrijk genocg voor, vooral omdat in onze Sociale Wetgeving - indien niet alle teekenen bedricgen - aan de uit de matschappij-zelve gegroeide organen ecne grootere plaats zal worden ingeruimd.

Mr. JAC. GROOTEN Jr.

\section{SCHANDELIJKE PRAKTIJKEN}

Een dezer dagen kwam mij een circulaire in handen, waarin twee Amsterdammers hume diensten als accountant aanbjeden. Ik zou den weg van dit rondschrijven nar den papiermand niet onderbroken hebben, indien het door een del vele onbevoegden in circulatie was gebracht. De onderteekenaars der circulaire deelen evenwel mede, dat zij het ,volledig accountants-diploma van het Nederlandsch Instituut van Accountants" bezitten. Een dergelijke ongevraagde aanbieding van diensten zal, - is de cerste overweging, - van ecn beroepsgenoot, die zichzelf respecteert, niet uitgaan. Dus werd de circulaire gelezen.

De inhoud is van dien aard, dat ik meen cen publick belang te dienen, dit geschrift hier van een kort commentaar te voolzien. Het beroep, dat deze heeren op het ,volledig accountantsdiploma van het Nederlandsch Instituut van Accountants" doen, doet wel zéér eigenaardig aan. Zij zijn zich wel bewust van de goede reputatie van het N.I.v.A. en het door hem uitgereikt ,volledig accountants-diploma". Vandaar, dat zij uitdrukkelijk aan beide refereeren. Zij zeggen er evenwel nog iets meer mede: „Wij hebben geprofiteerd van de vele offers, welke „dat Instituut gedurende een recks van jaren voor de vakoplei,ding heeft gebracht, doch zullen de verplichtingen, welke daar„uit moraliter" voortspruiten, niet honoreeren. Wij kunnen niet ,,tot de orde worden geroepen, want wij zijn geen leden van dat "Instituut".

De heeren bepalen zich er n.l. niet toc, humne diensten per circulaire aan te bieden, zooals dit bij neringdoenden e.d. wel voorkomt. Voor hun ,prijsopgaaf" zou een loodgieter's- of bchangersbaasje met eenig zelfrespect zich stellig schamen. Zichier de circulaire:

„Wij bieden U aan de overname van icderc bestaande ,accountantscontrole tegen de helft van de kosten die U „er nu voor betaalt. Onze jarenlange ervaring, benevens ,ons volledig accountants-diploma van het Nederlandsch "Instituut van Accountants garandecren $\mathrm{U}$ een gocde uit"voering".

I)it schijnt in hooge mate unfair, maar het is zéér dom. Ieder die v'an accountantsdiensten gebruik maakt, kan weten, dat de kosten als regel afhankelijk worden gesteld van den omvang der werkzaamheden, welke op vaktechnische gronden noodzakelijk blijken. De bepaling van het kostenbedrag pleegt dus steeds het resultaat van een serieuze berekening te zijn. Deze, ,accountants" berekenen niets. Zij richten zich, zeer kennclijk, niet op een goede beroepsuitoefening, doch trachten beroepsgenooten te verdringen door misleiding van hume opdrachtgevers, die als 
regel, den onvang der werkzaamheden, welke op vaktechnische gronden noodzakelijk zijn, nict kumnen beoordeelen.

Nog meer hebben deze heeren aan te bieden:

„Wij zijn bereid, indien U ons met Uwe accountants,,controle belast, Uwe hoofdbocken gratis bij te houden, ,waardoor de hooge kosten van het aanhouden van een „duren leider van Uwe administratieafdeeling overbodig "kan worden."

Alsof een behoorlijke (levende) leiding van een administratieve organisatie vervangen kan worden door het „gratis bijhouden der hoofdboeken" (door deze lieden)!

De cenige verklaring welke ik voor het ontstaan der circulaire hel, kunnen vinden is, dat de onderteckenaars er blijkbaar niet in gegslangd zijn een practijk op te bouwen en dit doel nu tot iederen prijs trachten te bereiken. In dezelfde circulaire warin zij humne geheele morcele bagage over boord zetten, doen zij tevens een beroep op het vertrouwen van het publiek. Want het nitgangspunt van de verhouding tusschen client en accountant is toch in de eerste plaats een groote mate van vertrouwen, dat in den accountant wordt gesteld.. De hecren zullen blịkkaar nog moeten ervaren, dat men op hunne wijze geen vertrouwen wekt. Hoogstens cen gevoel van wecrzin.

\section{A. H. GRONDEL}

\section{INZAKE REKEST VAN DE VEREENIGING VAN ACADE- MISCH GEVORMDE ACCOUNTANTS BETREFFENDE DE REGELING VAN DE ACCOUNTANTSEXAMENS}

Ilet vergt doorgaans eenig heen en weer geschrijf, roordat bij een polemiek het standpunt der wederzijdsche opponenten duidelijk wordt en de eigenlijke geschilpunten naar voren treden. Het hlịkt dan mat al te dikwijls, dat men langs elkaar heen prat, dan wel elkaar verkeerd interpreteert. Zoo verwijt Mr. v. G. zijn opponenten, dat zij de verecnigingsopleidingen zonder meer gelijk stcllen met de particuliere opleidingen voor andere beroepen. 7ulks echter ten onrechtc, door zijn opponenten wordt slechts de academische oplciding voor cen beroep gesteld tegenover de niet-academische opleiding daartoe en het verschil tussehen deze twee soorten van opleiding als prineipicel gekwalificeert. Dat er tusschen de nict-academische opleidingen onderling verschillen zịjn, wordt daarbij in het midden gelaten.

Men lian Mr. v. G. tongeven, dat zich bij geen enkel ander beroep het feit hocft voorgedaan, dat de opleiding er toe op zulk een krachtige wijze door de Besturen van ecnige vereeniging is ter hand genomen als bij het accountantsberoep. Maar die opleidingen, hoe goed zij overigens ook zijn, blijven nict-academische oplcidingen, zoodat men met een verwijzing naar do verschillen, die er tussehen die niet-academische opleidingen bestaan, niet kan bewijzen, dat er tussehen de beste van die nietacademische opleidingen en de academische opleiding geen principieel verschil bestaat.

Het hecft gecn zin verder te polemiseeren over de vraag, waarin dat principicele verschil nu bestaat. Men overtuigt elkaar toch niet, omdat het verschil in inzicht in deze voor een goed decl berust op cen wardeeringsoordeel, walujij men met logische argumenten doorgaans toch niet uitkomt. Slechts mag cr op gewezen worden, dat als kenmerk voor de academische opleiding beschouwd mag worden: het zich gedurende een paar jaar uitsluitend bezig houden met de beofening van een bepaalde wetenschap onder leiding van uitverkoren leerkrachten en in nauw contact met medestudecrenden.

Een ander punt, dat naar mịn gevoel in de onderhavige discussie vertroebelend werkt, is de verwarring tusschen doel en middel. Het sterkst komt dit tot uitdrukking in het jongste artikel van Mr. v. G. waar hij op pg. 119 schrijft : „......, dat al bestaat verschil in de wijze van studie tusschen de academische opleiding en die der drie vercenigingen en al berust eerstgenoemde opleiding natuurlijkerwijs op breederen gr'ondslag dan laatstgemelden, tusschen het doel dier opleidingen geen principieel verschil bestaat noch kan bestaan."

Natuurlijk bestaat er t.a.v. het doel eenstemmigheid, dat doel kan slechts zijn, te zorgen voor een goeden accountantsstand. De strijid gaat in deze echter on de vraag, met welk middel dit doel het best bereikt wordt. Bovenstaand citaat vormt intusschen de basis voor wat m.i. het sterkste argument in het betoog van $\mathrm{Mr}$. v. G. is; hịj wijst er n.l. op dat de vereenigingen er met hun opleidingen toch in geslaagd zijn cen gocden accountantsstand hier te lande te vormen. „Is het noodig," aldus Mr. v. G. ,bewijs te leveren voor mijn stelling, dat de langs den weg der drie verecnigingen gevormde accountants ook heden, wat bekwaamheid en betrouwbarheid betreft, minstens gelijk staan met de vooraanstaande accountants in clk ander beschaafd land? Hecft. ooit iemand vóór den heer Modderaar twijfel aan de bekwaamheid van de leden der drie vereenigingen durven uitspreken?"'

$\mathrm{Nu} z i j$ el in de allereerste plaats op gewezen, dat Mr. v. G. hier overdrijft ; een oppervlakkige kennisname van de geschicdenis van het accountantsberoep hier te lande is reeds voldoende om te doen inzien, dat het met de onderlinge waardecring van de opleiding der drie Jeidende vereenigingen niet altijd zoo botertje bij den boom is geweest, als uit hetgeen Mr. v. G. hier schrijft wel zou blijken.

1) redeneering van $\mathrm{Mr}$. v. G. leidt tot de conclusie, dat de academische acountantsopleiding eigenlijk overbodig is, immers de vereenigingen hebben blijk gegeven voor een goeden accountantsstand te kunnen zor gen. Ik heb er in mijn vorig artikel l'ceds op gewezen, dat het feit, dat drie instellingen van hoogel: onderwijs een academische accountantsopleiding hebben georganiseerd er op wijst, dat door menschen, die toch alleszins tot oordeelen in deze bevoegd zịjn, geoordeeld is, dat er wel degelijk behoefte aan een academische opleiding in deze bestalat. J) o hoogere cischen, die aan de acountants gesteld worden en nog gesteld zullen worden, als gevolg van het steeds meer ingewikkeld worden der economisehe verhoudingen, dienden dalartoe als drijfveer.

$\mathrm{Nu}$ hoede men zich voor overdrijuing; dit beteckent niet, dat, om het accountantswerk in al zijn geledingen goed te kunnen verrichten, persé een academische oplejding noodig is. Zulks is zeker niet het geval en zal ook in de toekomst nict het geval zijn.. Maar men vergete niet, dat de voorgestelde wettelijke regeling het accountantsberoep vijjlaat on slechts een bepaalde categorie van accountants wil kwalificecren. Het zijn nu deze gekwalificocrde accountants, die het hoogere accountantswerk, om het zoo cens uit te drukken, zullon krijgen te verrichten. Voor deze categoric van accountants is bedocld de door de opponenten van Mr. v. G. geponeerde stelling, dat de academische oplejding daarvoor de mest wenschelijke is.

Tel adstructie van deze stelling wijzen zij dan $0 . . m$. op de lijn, die el in de ontwikkeling van het accountantsberoep, in het bijzonder dan in de ontwikkeling van de opleiding aan te wijzen valt, n.l. het ontstaan en den groei van het academisch onderricht, nadat het beroep een bepaald peil bereikt hecft. Tevens kumnen zij er daarbij dan op wijzen, dat het accountantsberoep daalmede cen ontwikkeling door makt analoog aan de ontwikkeling van andere beroepen.

Ook hier dient men zich voor overdrijving te wachten. Het pleiten voor de academische opleiding als de meest wenschelịke betcekent niet, dat men de andere opleidingen als ondeugdelijk beschouwt en ergo ook degenen, die deze opleidingen volgden. Mr. v. G. wil zijn opponenten wel steeds in den mond leggen, 